\title{
Combining ability studies in restorer lines of sunflower (Helianthus annuus L.)
}

\author{
T. Rudra Gouda Mali Patil, Vikas V. Kulkarni ${ }^{2 *}$, Mallikarjun Kenganal' ${ }^{2}$, I. Shankergoud ${ }^{2}$ \\ and J. R. Diwan ${ }^{1}$ \\ ${ }^{1}$ Department of Genetics and Plant Breeding, University of Agricultural Sciences, Raichur-584104 (Karnataka), \\ INDIA \\ ${ }^{2}$ AICRP on Sunflower, Main Agricultural Research Station, University of Agricultural Sciences, Raichur-584104 \\ (Karnataka), INDIA \\ *Corresponding author. E-mail: vik_gene@rediffmail.com
}

Received: July 28, 2016; Revised received: November 22, 2016; Accepted: February 24, 2017

\begin{abstract}
The restorer lines are used to get fertile hybrids in hybrid seed production system of sunflower. Improvement of R-lines for fertility and oil content of sunflower is required to get desirable hybrids upon crossing. In the present study, 6 restorer lines were crossed in full diallele and both direct and reciprocal crosses along with parents were evaluated for their combining ability. The analysis of variance revealed higher magnitude of SCA variance than GCA variance for all the characters studied except for days to 50 per cent flowering. Among six parents, GMU-520 and R-GM-41 were best general combiner for plant height, head diameter, test weight and leaf size in the desired direction. However, GMU-520 has advantage of yield per plant and oil content. From 15 direct crosses R-GM-41 x R -GM-49 exhibited significant specific combining ability for viz., days to 50 per cent flowering $(-1.08)$, plant height (13.69), head diameter (4.79), leaf size (0.74), yield per plant (17.14), volume weight (2.54), test weight (1.75) and oil content (0.34) followed by RCR-630 x GMU-520, R-GM-41 x EC-602060, R-GM-49 x GMU-520 and EC-602060 x GMU-520 each exhibiting good specific combining ability for majority of characters. Among reciprocal crosses R-GM -41 x RCR-8 exhibited a high reciprocal effects for head diameter (4.57), yield per plant (15.16), test weight (2.02) and leaf size (0.75).
\end{abstract}

Keywords: Gca, Gene action, Restorer lines, Sca, Sunflower

\section{INTRODUCTION}

Sunflower (Helianthus annuus L.) is one of the important edible oilseed crops grown in the world after soybean and groundnut. It is an important source of edible and nutritious oil. Sunflower oil is a rich source of lenoleic acid (64\%) and 25-30 per cent of oleic acid which helps in washing out cholesterol deposition in the coronary arteries of the heart and thus is good for heart patients. Sunflower being cultivated over an area of 20 million hectares and production around 30 million tonnes world over. In India, sunflower is being grown over an area of 0.55 million hectares with a production of 0.42 million tonnes occupying about 2.75 and 1.4 per cent of global sunflower area and production respectively with the productivity of $752 \mathrm{~kg}$ per ha. The major sunflower producing states in India are Karnataka (0.21 mt), Andhra Pradesh (0.06 mt) and Maharashtra $(0.02 \mathrm{mt})$ contributing around 70 per cent of total India's production and in recent years, its cultivation is taken up in non-traditional states like Punjab, Haryana, Uttar Pradesh, Gujarat, Odisha, Bihar and West Bengal (Anonymous, 2016).

Thus, there is a thrust for improving productivity of oilseeds. Amongst the edible oilseed crops, it is unique in the sense, both varieties and hybrids are available for cultivation. Increase in productivity can be done by exploitation of untapped commercial yield reservoirs through hybridization programme by identifying superior and better lines and further their purity maintainance. The significant landmark in the development of sunflower hybrids was the discovery of Cytoplasmic Male Sterility by Leclercq (1969) and followed by fertility restoration system by Kinman (1970) provided the required breakthrough in the development of hybrids. In India it was introduced in the year 1969 and gained popularity as oilseed crop during 1980 with the development of first commercial sunflower hybrid BSH-1 by Seetharam (1980).

The cytoplasmic genetic male sterility system of male sterility is utilized for development of hybrid cultivars in sunflower which involves three lines A-line, B-line and R-line. The R-line is used as the fertile pollengiving parent in hybrid contribution along with fertility restoration. R-lines are chosen based on their ability to produce large amounts of pollen and anthers that are suitable for proper pollen dissemination. The R-lines 
are able to restore fertility to the hybrid progeny because they contain the nuclear restorer genes $R f 1$, $R f 2$. This superior combining ability is an important aspect of R-lines that plant breeders look for when trying to obtain high yielding hybrid combinations (Poehlman and Sleper, 1995). Hence, the experiment was conducted to identify restorer lines with good combining ability for yield and yield componenet traits.

\section{MATERIALS AND METHODS}

The present study was carried out at Main Agricultural Research Station, University of Agricultural Sciences, Raichur with evaluation of 30 hybrids during Kharif 2015-16. The 30 hybrids including both direct and reciprocal crosses were derived from six restorer lines RCR-630, RCR-8, R-GM-41, R-GM-49, EC-602060 and GMU-520 in full diallel fashion and these were evaluated in a randomized complete block design with three replications. Each entry was grown in $1.2 \times 3$ sq. $\mathrm{m}$ plot with a spacing of $60 \mathrm{~cm}$ between rows and 30 $\mathrm{cm}$ between plants. Standard agronomic practices as per recommendations in package of practices for sunflower were followed (DOR, 2005).

Combining ability analysis was made by the method I of model I (with reciprocal crosses) as given by Griffing (1956). Observations were recorded on randomly selected five plants in each replication for each entry on important attributes viz., days to $50 \%$ flowering, plant height $(\mathrm{cm})$, head diameter $(\mathrm{cm})$, days to maturity, leaf size $\left(\mathrm{dm}^{2}\right)$, yield per plant $(\mathrm{g})$, volume weight (g), 100-seed weight (g) and oil content (\%). Mean of five plants on quantitative observations from all three replication was used for the statistical analysis.

\section{RESULTS AND DISCUSSION}

Sunflower is one of the important oilseed crops of the country. Edible oil derived from this crop has more acceptability because of its nutritional superiority. There is wide gap between the realized yield levels and its genetic potential. Success of heterosis breeding in any crop depends on the choice of the parents. The concept of combining ability given by Sprague and Tatum (1942) reiterates the importance of suitable parents to nick well in the expression of heterosis. Thus, evaluation of various lines for their nick well ability is a pre-requisite for the final selection of potential lines in hybridization programme.

Mainly three factors govern the choice of lines to be used viz., per se performance of the lines, behavior of the lines in hybrid combination and genetic diversity between the parents. The nature of gene action governing the character is dependent on the genetic structure and divergence between the parents involved. Hence, it is advisable to estimate the potentiality of parents and hybrids. Inheritance of yield and yield attributing characters is a highly complex phenomenon as they were governed by polygenes. Since this does not follow common Mendelian inheritance involves use of biometrical techniques. Through systematic studies with regard to heterosis and combining ability which helps the breeders to assess the nature of gene action governing the traits in terms of additive or nonadditive gene action. (Bertan et al., 2010)

Analysis of variance for combining ability: From the analysis of variance for combining ability (Table 1), it was revealed that variance due to general combining ability was highly significant $(\mathrm{p}=0.01)$ for all the nine characters studied. The mean sum of squares of the specific combining abilities was also highly significant for all the characters studied. Similarly, reciprocal effects were also highly significant for all the ten charac-

Table 1. ANOVA for combining ability for yield contributing characters in $6 \times 6$ diallel crosses of sunflower.

\begin{tabular}{|c|c|c|c|c|c|c|c|c|c|c|}
\hline \multirow[b]{2}{*}{ Source } & \multirow[b]{2}{*}{ Df } & \multicolumn{9}{|c|}{ Mean Sum of Squares } \\
\hline & & $\begin{array}{c}\text { Days to } \\
50 \% \\
\text { Flowering }\end{array}$ & $\begin{array}{c}\text { Plant } \\
\text { Height } \\
(\mathrm{cm})\end{array}$ & $\begin{array}{c}\text { Head diam- } \\
\text { eter } \\
(\mathrm{cm})\end{array}$ & $\begin{array}{l}\text { Days to } \\
\text { maturity }\end{array}$ & $\begin{array}{c}\text { Leaf } \\
\text { size } \\
\left(\mathrm{dm}^{2}\right)\end{array}$ & $\begin{array}{c}\text { Yield } \\
\text { per } \\
\text { plant (g) }\end{array}$ & $\begin{array}{c}\text { Volume } \\
\text { weight } \\
\text { (g) }\end{array}$ & $\begin{array}{c}\text { Test } \\
\text { weight } \\
\text { (g) }\end{array}$ & $\begin{array}{l}\text { Oil Con- } \\
\text { tent (\%) }\end{array}$ \\
\hline GCA & 5 & $23.55^{\text {** }}$ & $1040.73^{* *}$ & $30.45^{* *}$ & $366.93^{* *}$ & $1.77^{* *}$ & $182.51^{* *}$ & $18.59^{* *}$ & $7.67^{* *}$ & $1.73^{* *}$ \\
\hline SCA & 15 & $2.48^{* *}$ & $459.39^{* *}$ & $26.14^{* *}$ & $34.62^{* *}$ & $1.15^{* *}$ & $376.32^{* *}$ & $28.28^{* *}$ & $1.59^{* *}$ & $2.04^{* *}$ \\
\hline $\begin{array}{l}\text { Recip- } \\
\text { rocals }\end{array}$ & 15 & $5.58^{* *}$ & $176.74^{* *}$ & $13.15^{* *}$ & $30.67^{* *}$ & $0.46^{* *}$ & $79.63^{* *}$ & $22.67^{* *}$ & $1.30^{* *}$ & $1.40^{* *}$ \\
\hline Error & 35 & 0.59 & 32.72 & 1.36 & 1.87 & 0.028 & 14.19 & 1.89 & 0.24 & 0.07 \\
\hline
\end{tabular}

$*=$ Significant at $5 \%$ probability, $* *=$ Significant at $1 \%$ probability

Table 2. GCA, SCA variance and their proportion for different characters in sunflower.

\begin{tabular}{llll}
\hline CHARACTERS & GCA VARIANCE & SCA VARIANCE & GCA/SCA RATIO \\
\hline Days to 50 per cent flowering & 1.91 & 1.89 & 1.011 \\
Plant Height (cm) & 84.00 & 426.66 & 0.197 \\
Head Diameter (cm) & 2.42 & 24.78 & 0.098 \\
Days to maturity & 30.42 & 32.75 & 0.929 \\
Leaf size $\left(\mathrm{dm}^{2}\right)$ & 0.14 & 1.12 & 0.129 \\
Yield per plant $(\mathrm{g})$ & 14.02 & 362.13 & 0.039 \\
Volume weight $(\mathrm{g})$ & 1.39 & 26.38 & 0.053 \\
Test weight $(\mathrm{g})$ & 0.62 & 1.34 & 0.461 \\
Oil content $(\%)$ & 0.14 & 1.97 & 0.070 \\
\hline
\end{tabular}


T. Rudra Gouda Mali Patil et al. / J. Appl. \& Nat. Sci. 9 (1): 603 - 608 (2017)

Table 3. Estimates of General combining ability effects of parents for various characters.

\begin{tabular}{|c|c|c|c|c|c|c|c|c|c|}
\hline Parents & $\begin{array}{l}\text { Days to } \\
50 \% \\
\text { flowering }\end{array}$ & $\begin{array}{l}\text { Plant } \\
\text { height (cm) }\end{array}$ & $\begin{array}{l}\text { Head di- } \\
\text { ameter } \\
\text { (cm) }\end{array}$ & $\begin{array}{l}\text { Days to } \\
\text { maturity }\end{array}$ & $\begin{array}{l}\text { Leaf } \\
\text { size } \\
\left(\mathrm{dm}^{2}\right)\end{array}$ & $\begin{array}{l}\text { Yield } \\
\text { per } \\
\text { plant }(\mathrm{g})\end{array}$ & $\begin{array}{l}\text { Volume } \\
\text { weight } \\
\text { (g) }\end{array}$ & $\begin{array}{l}\text { Test } \\
\text { weight } \\
\text { (g) }\end{array}$ & $\begin{array}{l}\text { Oil content } \\
(\%)\end{array}$ \\
\hline RCR-630 & $0.94^{* *}$ & $-10.52^{* *}$ & $-1.03^{* *}$ & $-3.99^{* *}$ & $-0.19^{* *}$ & $-3.92^{* *}$ & $1.67^{* *}$ & $-0.94^{* * *}$ & -0.03 \\
\hline RCR-8 & $-1.11^{* *}$ & $6.14^{* *}$ & $-1.56^{* *}$ & $-2.77^{* *}$ & -0.05 & $-2.24^{*}$ & -0.39 & $-0.46^{* *}$ & $0.18^{*}$ \\
\hline R-GM-41 & $1.92^{* *}$ & $12.01^{* *}$ & $0.95^{* *}$ & $9.15^{* *}$ & $0.26^{* *}$ & -0.80 & $-2.11^{* *}$ & $0.95^{* *}$ & $-0.15^{*}$ \\
\hline R-GM-49 & -0.11 & $-8.45^{* *}$ & $-0.67^{*}$ & $-4.80^{* *}$ & $-0.41^{* *}$ & -1.25 & 0.57 & $-0.66^{* *}$ & $-0.33^{* *}$ \\
\hline EC-602060 & $-1.97^{* *}$ & $-5.48^{* *}$ & -0.42 & $-1.93^{* *}$ & $-0.23^{* *}$ & 0.95 & 0.13 & $0.28^{*}$ & $-0.33^{* *}$ \\
\hline GMU-520 & 0.33 & $6.30^{* *}$ & $2.76^{* *}$ & $4.34^{* *}$ & $0.64^{* *}$ & $7.25^{* *}$ & 0.12 & $0.83^{* *}$ & $0.67^{* *}$ \\
\hline C. D@ $@ 5 \%$ & 0.52 & 3.87 & 0.79 & 0.93 & 0.11 & 2.55 & 0.93 & 0.33 & 0.18 \\
\hline C.D@1\% & 0.82 & 6.08 & 1.24 & 1.45 & 0.17 & 4.00 & 1.46 & 0.52 & 0.28 \\
\hline
\end{tabular}

$*=$ Significant at $5 \%$ probability, $* *=$ Significant at $1 \%$ probability

Table 4. Specific combining ability effects of various characters in sunflower.

\begin{tabular}{|c|c|c|c|c|c|c|c|c|c|}
\hline Crosses & $\begin{array}{l}\text { Days to } \\
\mathbf{5 0 \%} \\
\text { flowering }\end{array}$ & $\begin{array}{l}\text { Plant } \\
\text { height } \\
\text { (cm) }\end{array}$ & $\begin{array}{l}\text { Head } \\
\text { diame- } \\
\text { ter }(\mathrm{cm})\end{array}$ & $\begin{array}{l}\text { Days to } \\
\text { ma- } \\
\text { turity }\end{array}$ & $\begin{array}{l}\text { Leaf } \\
\text { size } \\
\left(\mathrm{dm}^{2}\right)\end{array}$ & $\begin{array}{l}\text { Yield } \\
\text { per } \\
\text { plant (g) }\end{array}$ & $\begin{array}{l}\text { Volume } \\
\text { weight } \\
\text { (g) }\end{array}$ & $\begin{array}{l}\text { Test } \\
\text { weight } \\
\text { (g) }\end{array}$ & $\begin{array}{l}\text { Oil } \\
\text { content } \\
(\%)\end{array}$ \\
\hline RCR-630 x RCR-8 & 0.72 & $7.93^{*}$ & $5.76^{* *}$ & $3.16^{* *}$ & $1.17^{* *}$ & $14.64^{* F^{\prime}}$ & 0.25 & $0.91^{* *}$ & -0.33 \\
\hline RCR-630x R-GM-41 & 0.53 & 2.76 & $-3.67^{* *}$ & $-4.59^{* *}$ & $-0.96^{* *}$ & $-9.67^{* *}$ & $4.79^{* *}$ & $-0.83^{*}$ & $1.07^{* *}$ \\
\hline RCR-630 xR-GM-49 & 0.56 & $-9.37^{*}$ & $-2.12^{* *}$ & -0.98 & $-0.49^{* *}$ & $-8.65^{* *}$ & $-3.09^{* *}$ & -0.44 & $-0.68^{* *}$ \\
\hline RCR-630x EC-602060 & -0.08 & 0.58 & -0.40 & -0.51 & 0.14 & -0.26 & $3.44^{* *}$ & -0.52 & $0.88^{* *}$ \\
\hline RCR-630 x R-6 & -0.39 & $11.64^{* *}$ & $3.45^{* *}$ & $1.88^{*}$ & $0.95^{* *}$ & $16.99^{* *}$ & -1.18 & $0.78^{*}$ & $0.37^{*}$ \\
\hline RCR-8 x R-GM-41 & 0.75 & $7.65^{*}$ & 0.75 & $3.85^{* *}$ & $0.35^{* *}$ & 0.36 & $2.98^{* *}$ & 0.47 & 0.09 \\
\hline RCR-8 x R-GM-49 & 0.11 & 1.61 & -1.36 & $-2.54^{* *}$ & 0.08 & 2.23 & -0.33 & -0.50 & -0.07 \\
\hline RCR-8 x EC-602060 & $2.31^{* *}$ & $13.59^{* *}$ & -0.83 & $5.94^{* *}$ & 0.09 & -4.59 & $-5.32^{* *}$ & -0.51 & $0.85^{* *}$ \\
\hline RCR-8 x R- 6 & $-1.00^{*}$ & $13.65^{* *}$ & 0.42 & $-3.01^{* *}$ & -0.21 & 1.73 & 1.72 & -0.03 & 0.27 \\
\hline R-GM-41 x R-GM-49 & $-1.08^{*}$ & $13.691^{* *}$ & $4.79^{* *}$ & $8.55^{* *}$ & $0.74^{* *}$ & $17.14^{* *}$ & $2.54^{* *}$ & $1.75^{* *}$ & $0.34^{*}$ \\
\hline R-GM-41 x EC-602060 & 0.28 & $12.55^{* *}$ & $3.62^{* *}$ & -0.98 & $0.58^{* *}$ & $20.21^{* *}$ & 0.85 & $0.81^{*}$ & $0.57^{* *}$ \\
\hline R-GM-41 x GMU-520 & -0.19 & $-21.06^{* *}$ & $-4.30^{* *}$ & -1.59 & $-0.69^{* *}$ & $-12.73^{* *}$ & $-4.84^{* *}$ & $-1.25^{* *}$ & $-0.80^{* *}$ \\
\hline R-GM-49 x EC-602060 & 0.14 & -3.15 & -1.37 & -0.70 & 0.03 & -3.77 & $3.91^{* *}$ & -0.53 & $0.73^{* *}$ \\
\hline R-GM-49 x R-6 & 0.50 & $14.90^{* *}$ & $4.02^{* *}$ & $-2.65^{* *}$ & $0.43^{* *}$ & $10.47^{* *}$ & 0.04 & 0.27 & $0.35^{*}$ \\
\hline EC-602060 x GMU-520 & -0.47 & -3.28 & 2.61 ** & $2.66^{* *}$ & $0.52^{* *}$ & $9.92^{* *}$ & $4.42^{* *}$ & $1.26^{* *}$ & $0.71^{* *}$ \\
\hline C.D $5 \%$ & 0.989 & 7.37 & 1.50 & 1.76 & 0.21 & 4.85 & 1.77 & 0.64 & 0.34 \\
\hline C. D $1 \%$ & 1.373 & 10.23 & 2.09 & 2.44 & 0.29 & 6.74 & 2.46 & 0.88 & 0.47 \\
\hline
\end{tabular}

$*=$ Significant at $5 \%$ probability, $* *=$ Significant at $1 \%$ probability

ters studied in a diallel design. Combining ability analysis is a powerful tool to discriminate good as well as poor combiners and it helps the breeder in selecting desirable parents and provides information on the relative importance of GCA and SCA for interpreting the genetic basis of important traits and their inheritance.

GCA and SCA variances for restorer lines: The estimates of general and specific combining ability variances and their relative magnitude are presented in the Table 2. The analysis of variance revealed higher magnitude of SCA variance than GCA variance for all the characters studied i.e., plant height, head diameter, days to maturity, leaf size, yield per plant, volume weight, test weight and oil content except days to 50 per cent flowering. The higher magnitude of SCA variance indicated the predominance of non-additive gene action for all these characters. Whereas for days to 50 per cent flowering higher magnitude of GCA variance than SCA variance was observed indicating the presence of additive gene action for this character which is in accordance with Ortis et al. (2005). For plant height and head diameter non additive gene action was reported by Manivannan et al. (2005), Reddy and Madhavilatha (2005), Pavani et al. (2006), Parameshwarappa et al. (2008), Mohanasundaram et al. (2010), Dudhe et al. (2011) and Shinde et al.(2016) in sunflower. With respect to days to maturity nonadditive gene action was earlier reported in sunflower by Reddy and Madhavilatha (2005), Pavani et al. (2006), Mohanasundaram et al. (2010) and Shinde et al. (2016). Non-additive gene action was noticed for leaf size in sunflower. Similar results were reported by Battacharya and Sarkar (1978), Sugoor et al. (1996) and Naik et al. (1999) in sunflower. Non-additive gene action was reported for volume weight and test weight (100 seed weight) in sunflower which were similar to earlier reports by Mohanasundaram et al. (2010). Similarly, for yield per plant and oil content were also governed by non-additive gene action in sunflower which were in accordance with Reddy and Madhavilatha (2005), Parameshwarappa et al. (2008), Dudhe et al. (2011), Patil et al. (2012), Jondhale et al. (2014) and Shinde et al. (2016).

General combining ability effects: The average performance of genotype in cross combinations with a set of other genotypes is called as general combining ability of the genotype and is expressed as gca effect $\left(g_{i}\right)$. General combining effects were estimated for six parents in diallel cross and are presented character wise in Table 3. 
Table 5. Reciprocal effects for various characters in sunflower.

\begin{tabular}{|c|c|c|c|c|c|c|c|c|c|}
\hline Crosses & $\begin{array}{l}\text { Days to } \\
50 \% \\
\text { flowering }\end{array}$ & $\begin{array}{l}\text { Plant } \\
\text { height } \\
\text { (cm) }\end{array}$ & $\begin{array}{l}\text { Head } \\
\text { diameter } \\
\text { (cm) }\end{array}$ & $\begin{array}{l}\text { Days to } \\
\text { maturity }\end{array}$ & $\begin{array}{l}\text { Leaf } \\
\text { size } \\
\left(\mathbf{d m}^{2}\right)\end{array}$ & $\begin{array}{l}\text { Yield per } \\
\text { plant (g) }\end{array}$ & $\begin{array}{l}\text { Volume } \\
\text { weight } \\
\text { (g) }\end{array}$ & $\begin{array}{l}\text { Test } \\
\text { weight } \\
\text { (g) }\end{array}$ & $\begin{array}{l}\text { Oil } \\
\text { content } \\
(\%)\end{array}$ \\
\hline RCR-8 x RCR-630 & 0.33 & $-13.80^{* *}$ & $4.88^{* *}$ & $4.33^{* *}$ & $0.70^{* 6}$ & $6.86^{* *}$ & $-3.05^{* 2 *}$ & $1.23^{* *}$ & $-1.12^{* *}$ \\
\hline R-GM-41 x RCR-630 & $3.83^{* *}$ & -6.88 & 0.40 & $4.17^{* *}$ & $-0.23^{*}$ & 0.04 & -0.90 & 0.20 & -0.25 \\
\hline R-GM-41 x RCR-8 & 0.00 & 5.55 & $4.57^{* *}$ & $4.50^{* *}$ & $0.75^{* *}$ & $15.16^{* *}$ & $-2.10^{*}$ & $2.02^{* *}$ & $-1.05^{* *}$ \\
\hline R-GM-49 x RCR-630 & -0.17 & -0.58 & -0.23 & $-1.83^{*}$ & 0.06 & -0.25 & -1.43 & -0.12 & -0.15 \\
\hline R-GM-49x RCR-8 & -0.67 & 2.88 & 0.20 & 0.17 & $-0.22^{*}$ & $4.97^{*}$ & $2.50^{* *}$ & 0.03 & $0.97^{* *}$ \\
\hline R-GM-49 x R-GM-41 & -0.50 & 4.17 & 0.33 & -0.17 & 0.13 & 0.26 & 0.12 & 0.23 & $1.28^{* *}$ \\
\hline EC-602060 x RCR-630 & -0.67 & $10.50^{* *}$ & $2.17^{* *}$ & 0.83 & $0.45^{* *}$ & -1.35 & 0.68 & 0.08 & 0.12 \\
\hline EC-602060 x RCR-8 & -0.33 & $8.83^{*}$ & 0.27 & $-9.83^{* *}$ & $-0.34^{* *}$ & 1.93 & $10.50^{* *}$ & -0.43 & -0.13 \\
\hline EC-602060 x R-GM-41 & $1.00^{*}$ & -1.67 & -0.70 & $4.17^{* *}$ & -0.05 & 1.48 & $-3.72^{* *}$ & -0.07 & $1.45^{* *}$ \\
\hline EC-602060 x R-GM-49 & $1.50^{* *}$ & 5.83 & 0.13 & $1.83^{*}$ & $0.23^{*}$ & 1.23 & 0.82 & 0.25 & $1.23^{* *}$ \\
\hline GMU-520x RCR-630 & $-2.00^{* *}$ & $-21.67^{* *}$ & $3.07^{* *}$ & 1.50 & $0.85^{* *}$ & $12.82^{* *}$ & -1.17 & $0.87^{*}$ & $-0.53^{* *}$ \\
\hline GMU-520x RCR-8 & $-1.33^{*}$ & -9.00 & $-3.37^{* *}$ & $-6.83^{* *}$ & $-0.58^{* *}$ & $-7.00^{* *}$ & 0.53 & $-1.23^{* *}$ & -0.08 \\
\hline GMU-520x R-GM-41 & $3.83^{* *}$ & $15.17^{* *}$ & $1.70^{*}$ & 1.17 & $-0.51^{* *}$ & 2.23 & $-2.88^{* *}$ & -0.48 & $-1.22^{* *}$ \\
\hline GMU-520 x R-GM-49 & 0.50 & 3.67 & $-2.10^{* *}$ & 0.17 & $-0.34^{* *}$ & -4.16 & $3.42^{* *}$ & $1.07^{* *}$ & -0.18 \\
\hline GMU-520x EC-602060 & $-1.33^{*}$ & 3.55 & $-4.50^{* *}$ & 1.33 & $-0.69^{* *}$ & $-7.11^{* *}$ & -0.55 & 0.40 & 0.08 \\
\hline C. D@ $95 \%$ & 1.16 & 8.67 & 1.77 & 2.07 & 0.41 & 5.71 & 2.09 & 0.75 & 0.39 \\
\hline C. D@1\% & 1.62 & 12.04 & 2.45 & 2.87 & 0.57 & 7.93 & 2.89 & 1.04 & 0.55 \\
\hline
\end{tabular}

$*=$ Significant at $5 \%$ probability, $* *=$ Significant at $1 \%$ probability

Among the six restorer lines used in the study parent GMU-520 had shown significant high gca effect for the characters plant height, head diameter, yield per plant, test weight, leaf size and most importantly for oil content. The parent R-GM-41 had high gca effect for plant height, head diameter, test weight and leaf size in desired direction. Parent RCR- 8 had good gca effect for the traits like days to fifty per cent flowering and oil content. Whereas parent RCR-630 had good gca in the desirable direction for days to maturity and volume weight.

It is evident from the results that there is no single restorer parent having good general combining effects for all the characters studied in the desired direction. However, the parent GMU-520, exhibited significant $(p=0.01 \%)$ general combining ability effects for maximum number of characters viz., plant height, head diameter, yield per plant, volume weight, test weight, oil content and leaf size followed by parent R-GM-41 for plant height, head diameter, test weight and leaf size. The above sunflower results are in agreement with Giriraj (1987), Javed and Aslam (1995), Bajaj et al. (1997), Sharma et al. (2003) and Reddy and Madhavilatha (2005). As sunflower is an oilseed crop, there is a need for combining both yield per plant and oil content in hybrids. In this direction GMU-520 has been a good general combiner for both yield per plant as well as for oil content.

Specific combining ability effects: The relative performance of any cross combination is expressed as specific combining ability and is denoted in terms of $s c a$ effects $\left(\mathrm{S}_{\mathrm{ij}}\right)$. Specific combining ability effects are indicative of heterosis and represent both dominance and epistatic gene action. The superior parental combination having sca effects for yield and its component characters are presented in Table 4. The prior knowledge about specific combining ability is very important in order to select a suitable hybrid from the crosses.

The cross R-GM-41 x R-GM-49 exhibited good significant specific combining ability for as many as eight characters studied viz., days to 50 per cent flowering, plant height, head diameter, leaf size, yield per plant, volume weight, test weight and oil content followed by RCR-630 x GMU-520, R-GM-41 x EC-602060, R-GM $-49 \times$ GMU-520 and EC-602060 x GMU-520, each exhibited good specific combining ability for 7 different yield contributing characters. The cross RCR-630 x RCR-8 exhibit a specific combining ability for plant height, head diameter, yield per plant, test weight and leaf size. Whereas cross RCR-630 x R-GM-41 is good specific combiner for oil content, days to maturity and volume weight.

In the present investigation, all four types of parental combinations i.e., high $\mathrm{x}$ high, high $\mathrm{x}$ low, low $\mathrm{x}$ high and low $\mathrm{x}$ low were observed in 15 crosses. However, majority of crosses exhibited high sca effects as either of low x low or high x low gca parents indicating a genetic interaction of either dominance $\mathrm{x}$ dominance or additive $\mathrm{x}$ dominance interaction respectively these results are in agreement with earlier reports of Naik et al. (1999) and Sugoor et al. (1996) in sunflower.

For most of the characters studied, the low x low gca combination of parents were noticed in heterotic cross combinations, indicating the predominance of nonadditive gene action and very less of additive gene action in these crosses. These findings are in agreement with earlier reports of sunflower studies by Kandalkar (1997) and Reddy and Madhavilatha (2005). It is desirable to select the crosses showing high sca effect with high gca effect parents, where both additive and non-additive gene actions can be utilized. However, very few crosses confirmed to this observation. The high $\mathrm{x}$ low or low $\mathrm{x}$ high crosses, besides exhibiting 
the favorable additive effect of the high gca parent, complement the epistatic effects in the cross, which would finally manifest in to higher sca effects.

Reciprocal effects: Reciprocal effects were significant for all characters studied. The present study revealed that no single cross is significant for reciprocal effect for all the characters in the desired direction (Table 5). However, reciprocal cross R-GM-41 x RCR-8 exhibited a high reciprocal effects for the characters head diameter, yield per plant, test weight and leaf size. The cross GMU-520 x RCR-8 exhibited high reciprocal effect for days to 50 per cent flowering, days to maturity and leaf size. EC-602060 x R-GM-41 exhibited reciprocal effects for important characters i.e., oil content as sunflower is an oil seed crop this character is important character which directly influence oil yield. Whereas crosses RCR-8 x RCR-630, R-GM-41 x RCR -8 and GMU-520 x RCR-630 had significant reciprocal effect for head diameter, yield per plant, test weight and leaf size, the cross GMU-520 x RCR-630 also had significance for days to 50 per cent flowering. The crosses EC-602060 x R-GM-41 and R-GM-49 x RGM-41 had significant reciprocal effect for oil content. The cross R-GM-41 x RCR- 8 exhibited no reciprocal effect for days to fifty percent flowering. The reciprocal differences may be due to cytoplasmic influence on inheritance of character. Similar results of reciprocal effect were reported Shashikumar (2007) for 50 per cent flowering, test weight and oil content in sunflower.

\section{Conclusion}

The estimates of GCA: SCA ratio (Variance ratio) were less than unity for all the characters viz., plant height, head diameter, days to maturity, leaf size, yield per plant, volume weight, test weight and oil content of sunflower indicating relatively higher proportion of sca responsible for the expression of major yield contributing traits except for days to 50 per cent flowering, hence governed non-additive gene action for majority of traits. The parent GMU-520 was best general combiner for most of the yield contributing characters viz., plant height, head diameter, yield per plant, test weight, leaf size and most importantly for oil content which can be further utilized for heterosis breeding. Analysis of specific combining ability revealed that, no single cross had a good specific combining ability effects for all the characters studied, however, the cross R-GM-41 x R-GM-49 exhibit higher sca effects for majority characters except days to maturity. Similarly, for reciprocal effects, the cross R-GM-41 x RCR-8 exhibited high reciprocal effect for maximum number of character.viz., head diameter, days to maturity, leaf size, yield per plant and test weight in sunflower. From the superior crosses obtained in the present study selection can be made in advanced generations to derive a good restorer inbred line and these were further tested for combining ability with male sterile lines to derive new high yielding heterotic hybrid.

\section{REFERENCES}

Anonymous. (2016). Annu. Rep. of Sunflower. Indian Institute of Oilseed Research, Hyderbad Pp.13 - 14.

Bajaj, R. K., Ahuja, K. and Chahal, G. S. (1997). Combining ability studies in sunflower (Helianthus annuus L.). Crop Improv., 24(1): 50-54

Battacharya, B. and Sarkar, R. (1978). Relationship between growth parameters, assimilation rate and seed yield in sunflower under varying irrigation levels. Indian Agriulturist, 22(4): 237-241

Bertan. I., De Carvalho, F. I. F. and De Oliveira, A. C., (2010). Parental selection strategies in plant breeding programmes. J. Crop Sci. Biotech., 10 (4): 211-222.

DOR. (2005). Sunfower: package of practices for increasing production. Directorate of Oilseed Research, Hyderbad, 3:1-17

Dudhe, M. Y., Moon, M. K., and Lande, S. S. (2011). Study of gene action for restorer lines in sunflower. Helia., 34 (54): 159-164

Giriraj, K., Shantha, R., Hiremath and Seenappa, K. (1987). Combining ability of converted male sterile lines of sunflower (Helianthus annuus L.). Ind. J. Genet., 47: 315-317

Griffing, B. (1956). Concept of general and specific combining ability in relation to diallel crossing systems. Australian journal of biological sciences, 9: 463-493

Javed, N. and Aslam, M. (1995). Combining ability effects in sunflower F1 hybrids. Helia, 18: 41-45

Jondhale, A. S., Shanker Goud, I. and Praveen kumar. (2014). Combining ability and gene action studies in diverse CMS sources in sunflower (Helianthus annuus L.). Int. J. Sci. Res., 3(12): 2183-2187

Kandalkar, V. S. (1997). Phenotypic stability analysis in open pollinated varieties of sunflower (Helianthus annuus L.) in North West and South East Madhya Pradesh during winter season. Ind. J. Agric. Sci., 67: 606607

Kinman, M. L. (1970). New development in the USDA and State Experiment Station, sunflower breeding programme. In: Proc. of the Fourth Int. Sunflower Conference., Memphis, Tennessa Pp. 181-183

Leclercqe, P. (1969). Line sterile cytoplasmique chezk tournesol. Ann. Amelior Planta., 12: 99-106

Manivannan, P., Vidyavathi and Muralidharan, V. (2005). Diallel analysis in sunflower. Ind. J. Agric. Res., 39(4): 281-285

Mohanasundaram, K., Manivannan, N. and Varman, P. V. (2010). Combining ability analysis for seed yield and its components in Sunflower. Elec. J. Pl. Breed., 1(4): 864 $-868$

Naik, V., Shanta, R., Hiremath and Giriraj, K. 1999. Gene action in sunflower. Karnataka J. Agric. Sci., 12:43-47

Ortis, L., Nestures, G., Frutos, E. and Machado, N. (2005). Combining ability analysis for agronomic traits in sunflower (Helianthus annus L.). Helia., 28: 125-134

Parameshwarappa, K.G., Sharma, J. and Lingaraju, B.S. (2008). Heterosis and combining ability for seed yield, oil content and other agronomic traits involving mutant restorer lines in sunflower (Helianthus annuus L.). J. 
Oilseeds Res., 25 (1): 8-12

Patil, R., Shaker Goud, I., Kulkarni, V. V. and Banakar, C. (2012). Combining ability and gene action studies for seed yield and its components in sunflower (Helianthus annuus L.). Elec. J. Pl. Breed., 3(3): 861-867

Pavani, E., Bharathi, M., Vishnuvardhan Reddy, A. and Madhavi Latha, K. (2006). Combining ability studies in sunflower (Helianthus annuus L.). J. Oilseeds Res., 23 (2): $168-170$

Poehlman, J. M. and Sleper, D. A. (1995). Breeding field crops. 4th ed. Iowa State University Press, Ames.

Reddy, A., and Madhavilatha, K. (2005). Combining ability for yield and yield components in sunflower. J. Res., Acharya N. G. Ranga Agric. Univ., 33(2): 12-17

Seetharam, A. (1980). Hybrid sunflower. Indian Farming., 24: $15-16$

Sharma, S., Bajaj, R. K., Kaur, N. and Seghal, S. K. (2003).
Combining ability studies in sunflower (Helianthus annuus L.). Crop Improv., 30(1): 69-73

Shashikumar, R. S. (2007). Phenotypic characterization and dillele analysis of restorer lines in sunflower (Helianthus annuus L.). M. Sc. (Agri) Thesis, Univ. Agric. Sci., Dharwad (India).

Shinde, S. R., Sapkale, R. B. and Pawar, R. M. (2016). Combining ability analysis for yield and its components in sunflower (Helianthus annuus L.). Internat. J. agric. Sci., 12 (1): 51-55

Sprague, G. F., and L. A. Tatum. (1942). General vs. specific combining ability in single crosses of com. J. Am. Soc. Agr., 34:923-932

Sugoor, K. R., Giriraj, K. and Salimath, P. M. (1996). Heterosis for yield and earliness I crosses involving induced mutant restorer lines of sunflower. J. Maharashtra Agric. Univ., 21 (3): 467-468 